Article

\title{
Enhanced phenol hydroxylation with oxygen using a ceramic membrane distributor
}

\author{
CHEN Rizhi *, BAO Yaohui, XING Weihong, JIN Wanqin, XU Nanping \\ State Key Laboratory of Materials-Oriented Chemical Engineering, Nanjing University of Technology, Nanjing 210009, Jiangsu, China
}

\section{A R T I C L E I N F O}

\section{Article history:}

Received 30 November 2012

Accepted 20 December 2012

Published 20 January 2013

\section{Keywords:}

Phenol

Hydroxylation

Oxygen

Ceramic membrane

Membrane distributor

\begin{abstract}
A B S T R A C T
$\mathrm{A} \mathrm{CuO} / \mathrm{TiO}_{2}$ catalyst was prepared by impregnation and characterized by X-ray diffraction, transmission electron microscopy, and temperature-programmed reduction. Two types of dispersed species formed on the $\mathrm{TiO}_{2}$ surface, which were possibly isolated and polymeric $\mathrm{CuO}$ species. The $\mathrm{CuO}$ catalyst interacted strongly with the $\mathrm{TiO}_{2}$ support. A porous ceramic membrane was used as a distributor to control the supply of oxygen in phenol hydroxylation over the $\mathrm{CuO} / \mathrm{TiO}_{2}$ catalyst. Compared to a direct feed of oxygen without a membrane, the yield of dihydroxybenzene (DHB) increased by $13 \%$ using a porous ceramic membrane with a pore size of $0.5 \mu \mathrm{m}$ as an oxygen distributor. This is because the membrane distributor produced numerous small oxygen bubbles, increasing the volumetric oxygen transfer coefficient and gas-liquid mass transfer. Optimizing reaction conditions resulted in a yield of DHB of $2.5 \%$. Scanning electron microscope observation of the used ceramic membrane showed that it possessed excellent thermal and chemical stability.
\end{abstract}

(C) 2013, Dalian Institute of Chemical Physics, Chinese Academy of Sciences. Published by Elsevier B.V. All rights reserved.

\section{Introduction}

Dihydroxybenzene (DHB) compounds including hydroquinone and catechol are important chemical intermediates [1]. Phenol hydroxylation is a green route to synthesize DHB that has attracted considerable attention. The main oxidants used in phenol hydroxylation include hydrogen peroxide [2,3] and oxygen [4]. Oxygen is an excellent oxidizing agent because it is inexpensive, environmentally benign, and resists further oxidation.

Phenol hydroxylation using oxygen is limited by the activation of oxygen and mass transfer. One way to improve mass transfer is to use porous ceramic membranes that contain numerous micro- or nanosized pores as distributors. Such membranes control the supply of oxygen by forcing it to form many small bubbles, which increases gas-liquid mass transfer and thus promotes the reaction. Membrane distributors have been investigated extensively. Coronas et al. [5] used ceramic membranes as oxygen distributors in the oxidative coupling of methane. The selectivity using ceramic membranes was significantly higher than that using a fixed-bed reactor. We have used a ceramic membrane as a reactant distributor to control the supply of $\mathrm{H}_{2} \mathrm{O}_{2}$ in phenol hydroxylation over titanium silicalite catalyst [6], improving the selectivity for DHB. However, using a ceramic membrane as a distributor to control the supply of oxygen in phenol hydroxylation has not been reported.

In the present work, we use a porous ceramic membrane as a distributor to control the supply of oxygen in phenol hydroxylation over a $\mathrm{CuO} / \mathrm{TiO}_{2}$ catalyst in an attempt to enhance gas-liquid mass transfer and increase the yield of DHB. The $\mathrm{CuO} / \mathrm{TiO}_{2}$ catalyst was prepared by impregnation and characterized by X-ray diffraction (XRD), transmission electron microscopy (TEM), and temperature-programmed reduction (TPR). The sulphate method was used to measure the volumet-

\footnotetext{
* Corresponding author. Tel: +86-25-83172286; Fax: +86-25-83172292; E-mail: rizhichen@njut.edu.cn

This work was supported by the National Key Technology R\&D Program (2011BAE07B05), the National High Technology Research and Development Program of China (863 Program, 2012AA03A606) and the National Natural Science Foundation of China $(20990222,21106061)$.

DOI: 10.1016/S1872-2067(11)60512-3
} 
ric oxygen transfer coefficient of the system. The effect of the membrane distributor on the yield of DHB was investigated, and the reaction conditions were optimized.

\section{Experimental}

\subsection{Preparation and characterization of catalyst}

Copper catalysts are used in a wide range of organic syntheses, especially in liquid phase oxidation of aromatic compounds [7-10]. Highly dispersed copper species are considered the active sites in phenol hydroxylation [10]. Here, a $\mathrm{CuO} / \mathrm{TiO}_{2}$ catalyst was prepared by impregnation for use in phenol hydroxylation with oxygen. $\mathrm{Cu}\left(\mathrm{NO}_{3}\right)_{2} \cdot 3 \mathrm{H}_{2} \mathrm{O}$ (AR, Shanghai Sinpeuo Fine Chemical Co., Ltd., China) and anatase $\mathrm{TiO}_{2}$ (Qingdao Panzhihua Titanium Company, China) were added to deionized water $(50 \mathrm{ml})$. The solution was magnetically stirred for $8 \mathrm{~h}$ and then evaporated under reduced pressure. The residue was dried at $373 \mathrm{~K}$ overnight and calcined at $673 \mathrm{~K}$ in air for $5 \mathrm{~h}$. The $\mathrm{CuO}$ loading was $7 \mathrm{wt} \%$.

XRD was carried out on a diffractometer (Bruker D8 Advance, Germany) using $\mathrm{Cu} K_{\alpha}$ radiation at $40 \mathrm{kV}$ and $30 \mathrm{~mA}$ with a scanning rate of $0.2^{\circ} \mathrm{s}$. TPR was conducted using an analyzer (BELCAT-A, BEL, Japan). Prior to reduction, the sample was pretreated in an Ar stream at $573 \mathrm{~K}$ for $2 \mathrm{~h}$ and then cooled to $323 \mathrm{~K}$. The sample was then exposed to an $\mathrm{H}_{2} / \mathrm{Ar}$ mixture $(10 \%$ $\mathrm{H}_{2}$ by volume) and the temperature was raised to $1023 \mathrm{~K}$ at a rate of $10 \mathrm{~K} / \mathrm{min}$. The consumption of $\mathrm{H}_{2}$ in the reactant stream was detected by a thermal conductivity cell. The catalyst morphology was examined by TEM (JEM-2011, JEOL, Japan) operating at $200 \mathrm{kV}$. Samples were prepared for TEM observation by sonication in ethanol for 10 min and subsequent deposition onto carbon-coated copper grids.

\subsection{Phenol hydroxylation}

Phenol hydroxylation with oxygen was carried out in the system depicted in Fig. 1, which consisted of a slurry reactor, membrane module, heating system, and oxygen cylinder. The slurry reactor was made of glass and possessed a working volume of $250 \mathrm{ml}$. Ceramic membranes with an outer diameter of $12 \mathrm{~mm}$, inner diameter of $8 \mathrm{~mm}$, and length of $6 \mathrm{~cm}$ were provided by Jiangsu Jiuwu Hi-Tech Co., Ltd., China. One end of the membrane tube was sealed by glazing, and the other end was connected to the oxygen cylinder. During the reaction, the oxygen flowed into the membrane tube, and then passed through the membrane pores into the reaction solution to participate in the reaction. The oxygen flow was controlled by a pneumatic rotameter.

Ascorbic acid (AR grade, Shanghai Sinopharm Chemical Reagent Co., Ltd., China), $\mathrm{CuO} / \mathrm{TiO}_{2}$ catalyst, phenol $(20 \mathrm{ml}, \mathrm{AR}$ grade, Shanghai Sinopharm Chemical Reagent Co., Ltd., China), and aqueous acetic acid (200 ml, AR grade, Shanghai Shenbo Chemical Co., Ltd., China) were added to the reactor. The stirred mixture was heated to $308 \mathrm{~K}$. Oxygen was then flowed into the reactor to start the phenol hydroxylation.

The products were analyzed by a high-performance liquid

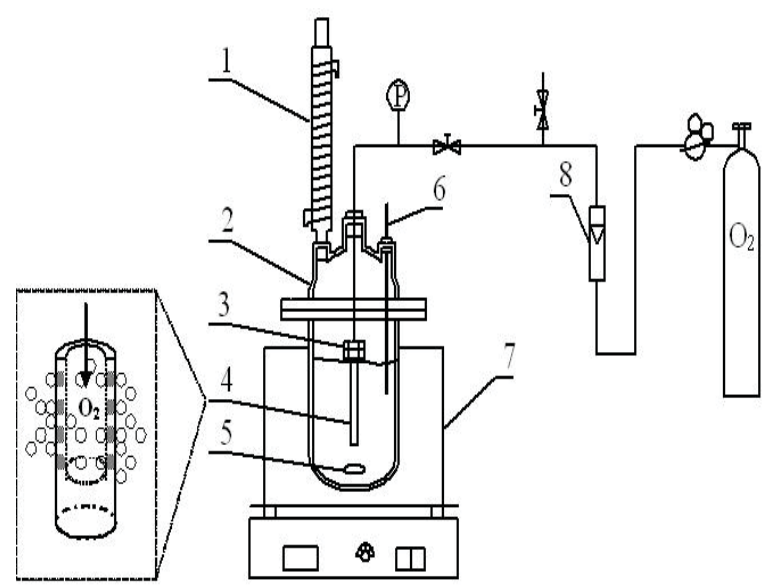

Fig. 1. Experimental setup for phenol hydroxylation using oxygen as the oxidizing agent. 1: condenser pipe; 2 : reactor; 3 : membrane module; 4 : membrane; 5: rotator; 6: thermometer; 7: water bath; 8: pneumatic rotameter

chromatograph (HPLC, Agilent 1200 Series, USA) equipped with a diode array detector and an auto-sampler. Chromatographic separations were performed at $303 \mathrm{~K}$ using a column (ZORBAX Eclipse XDB-C18, $4.6 \mathrm{~mm} \times 250 \mathrm{~mm}$ ). A mobile phase composed of $40 \%$ methanol and $60 \%$ water at a flow rate of 1 $\mathrm{ml} / \mathrm{min}$ was used. A wavelength of $277 \mathrm{~nm}$ was used to monitor the separation and the injection volume was $5 \mu \mathrm{l}$.

The morphology of the membranes was examined using a field emission scanning electron microscope (FESEM, Hitachi S-4800, Hitachi, Japan).

\section{Results and discussion}

\subsection{Characterization of catalyst}

\subsubsection{XRD results}

XRD patterns of the $\mathrm{CuO} / \mathrm{TiO}_{2}$ catalyst and $\mathrm{TiO}_{2}$ are presented in Fig. 2. Compared with the XRD pattern of $\mathrm{TiO}_{2}$, two obvious peaks at $2 \theta=35.5^{\circ}$ and $39.0^{\circ}$ were observed in that of the catalyst, corresponding to the (-111) and (111) crystal faces of monoclinic $\mathrm{CuO}$. The intensity of these $\mathrm{CuO}$ peaks was weak, possibly because of the small particle size or low crystallinity of $\mathrm{CuO}$.

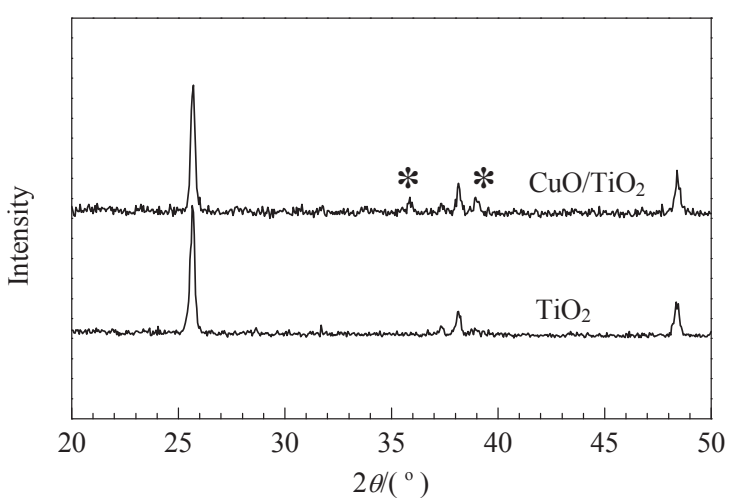

Fig. 2. XRD patterns of the $\mathrm{CuO} / \mathrm{TiO}_{2}$ catalyst and $\mathrm{TiO}_{2}$. 


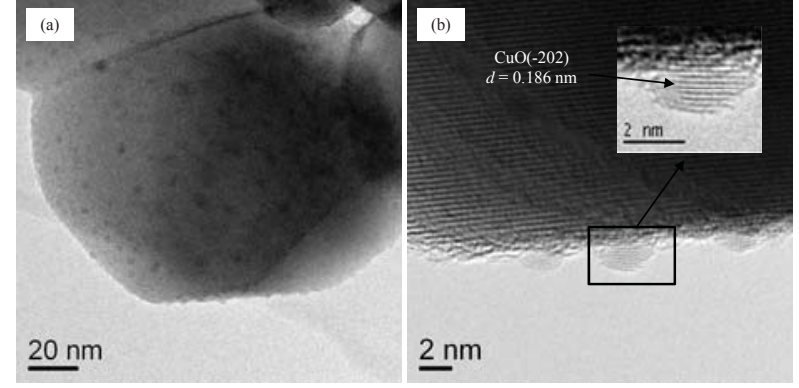

Fig. 3. TEM and HRTEM images of the $\mathrm{CuO} / \mathrm{TiO}_{2}$ catalyst. (a) TEM image of $\mathrm{CuO} / \mathrm{TiO}_{2}$; (b) HRTEM image of $\mathrm{CuO} / \mathrm{TiO}_{2}$. Inset: Fourier reconstruction of the area indicated by a rectangle.

\subsubsection{TEM results}

TEM and HRTEM images of the $\mathrm{CuO} / \mathrm{TiO}_{2}$ catalyst are shown in Fig. 3. $\mathrm{CuO}$ particles with a size of about $3 \mathrm{~nm}$ were well dispersed on the surface of the $\mathrm{TiO}_{2}$ support. The lattice spacing of $0.186 \mathrm{~nm}$ was consistent with the (-202) crystal face of $\mathrm{CuO}$.

\subsubsection{TPR results}

TPR characterization of the $\mathrm{CuO} / \mathrm{TiO}_{2}$ catalyst (Fig. 4) revealed that it exhibited three separate reduction peaks centered at 443,541 , and $610 \mathrm{~K}$, and the areas of the peaks at 541 and $610 \mathrm{~K}$ were obviously larger than that at $443 \mathrm{~K}$. Lasson et al. [11] attributed the peak at $443 \mathrm{~K}$ to the reduction of isolated $\mathrm{CuO}$ species, and those in the region of $503-553 \mathrm{~K}$ to the reduction of polymeric species. The peak at $610 \mathrm{~K}$ also might be related to the reduction of polymeric species interacting more strongly with the $\mathrm{TiO}_{2}$ support than those corresponding to the peak at $541 \mathrm{~K}$. These results indicate that there are both isolated and polymeric $\mathrm{CuO}$ species on the $\mathrm{TiO}_{2}$ surface, with a larger proportion of polymeric $\mathrm{CuO}$ species than isolated ones.

\subsection{Effect of membrane distributor on phenol hydroxylation}

The volumetric oxygen transfer coefficient was measured by the sulphate method [12] as a performance index for oxygen transfer. As shown in Table 1, when an alumina membrane with a pore size of $0.5 \mu \mathrm{m}$ or a mullite membrane with a pore

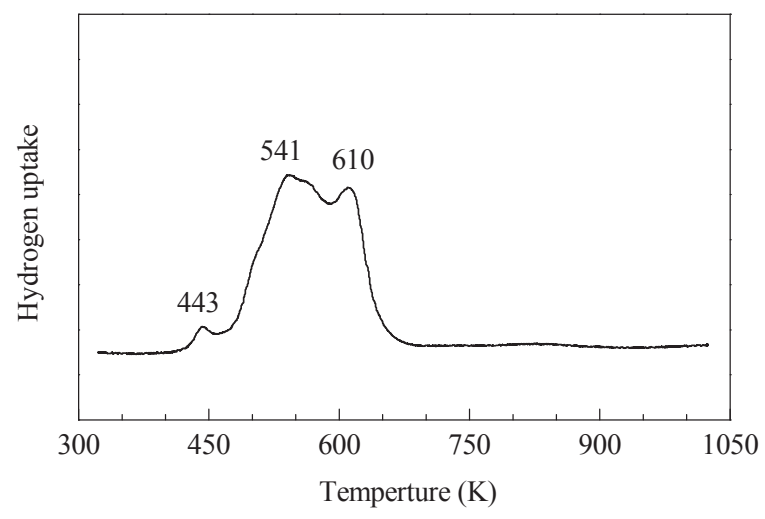

Fig. 4. TPR profile of the $\mathrm{CuO} / \mathrm{TiO}_{2}$ catalyst.
Table 1

Effect of membrane distributor on the volumetric oxygen transfer coefficient.

\begin{tabular}{lcc}
\hline Feeding mode & $\begin{array}{c}\text { Pore size or diameter } \\
(\mu \mathrm{m})\end{array}$ & $\begin{array}{c}k_{\mathrm{L}} a^{\text {a }} \\
\left(\mathrm{h}^{-1}\right)\end{array}$ \\
\hline Alumina membrane & 0.5 & 1183 \\
Mullite membrane & 1 & 1173 \\
PU tube & 4400 & 145 \\
\hline
\end{tabular}

a Volumetric oxygen transfer coefficient.

size of $1 \mu \mathrm{m}$ was used as a distributor to control the supply of oxygen in phenol hydroxylation, the volumetric oxygen transfer coefficient was about eight times higher than that in direct feeding mode when a PU tube was used to supply oxygen. This is because the membrane distributor created many small oxygen bubbles, which increased the gas-liquid mass transfer area and enhanced the mass transfer capacity of oxygen.

Alumina and mullite membranes with pore sizes of 0.5 and $1 \mu \mathrm{m}$, respectively, were used as distributors to control the supply of oxygen in phenol hydroxylation. The direct feeding mode was also used for comparison. As presented in Fig. 5, the yield of DHB increased when a ceramic membrane distributor was used. The ceramic membrane distributor with a pore size of $0.5 \mu \mathrm{m}$ increased the yield of DHB by $13 \%$. In addition, the stirring rate had an obvious effect on the yield of DHB, as shown in Fig. 6. The yield of DHB increased as the stirring rate was increased in the experimental range. Therefore, the reaction process was diffusion controlled. Combining these results with those in Table 1 revealed that introducing a membrane distributor into the reactor increased both the volumetric oxygen transfer coefficient and mass transfer capacity of oxygen. Therefore, the observed increase of the yield of DHB should be caused by the enhanced gas-liquid mass transfer related to the introduction of a membrane distributor. Figure 5 also shows that the yield of DHB first increased and then remained constant after a certain period, which should be related to the type of phenol conversion and selectivity for DHB changing. The conversion of phenol generally increased over time, whereas the selectivity for DHB decreased (data not shown here). The decrease of selectivity for DHB was caused by the further oxidation of DHB to benzoquinone and other by-products [6]. In-

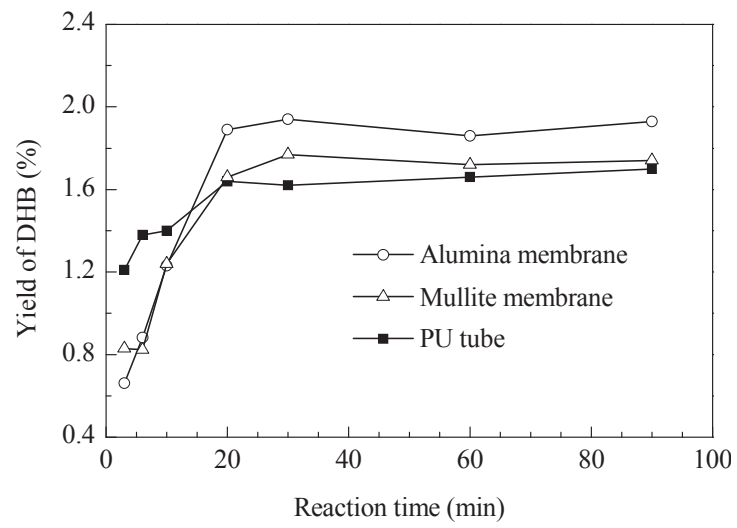

Fig. 5. Effect of membrane distributor on the yield of DHB. Reaction conditions: stirring rate $470 \mathrm{r} / \mathrm{min}$, oxygen flow $100 \mathrm{ml} / \mathrm{min}$, catalyst concentration $48.8 \mathrm{~g} / \mathrm{L}$, ascorbic acid concentration $50 \mathrm{~g} / \mathrm{L}$, acetic acid concentration $80 \%$. 


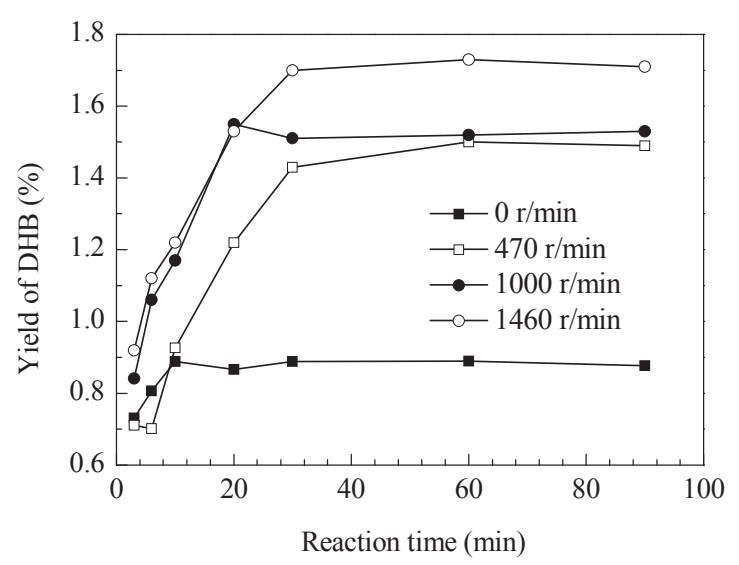

Fig. 6. Effect of stirring rate on the yield of DHB. Reaction conditions: oxygen flow $100 \mathrm{ml} / \mathrm{min}$, catalyst concentration $43.8 \mathrm{~g} / \mathrm{L}$, ascorbic acid concentration $40 \mathrm{~g} / \mathrm{L}$, acetic acid concentration $60 \%$.

troducing a membrane distributor caused a smaller increase in the yield of DHB than that of volumetric oxygen transfer coefficient. This indicates that the reaction process was also affected by other factors such as stirring rate and oxygen flow. A membrane distributor with smaller pore size promoted the synthesis of DHB more than one with larger pores. However, the required operation pressure obviously increases with decreasing membrane pore size. As a result, an alumina membrane with a pore size of $0.5 \mu \mathrm{m}$ was chosen as the oxygen distributor in phenol hydroxylation.

\subsection{Optimization of operating conditions}

\subsubsection{Effect of stirring rate}

Figure 6 shows the effect of stirring rate on phenol hydroxylation. The yield of DHB increased with stirring rate because an increased stirring rate reduced diffusion resistance, which promoted the reaction. The yield of DHB was $1.7 \%$ at a stirring rate of $1460 \mathrm{r} / \mathrm{min}$, almost twice that without stirring. However, the membrane tube might not effectively contact the reaction solution at higher stirring rates. Therefore, the optimum stirring rate was $1460 \mathrm{r} / \mathrm{min}$.

\subsubsection{Effect of oxygen flow rate}

The yield of DHB increased with oxygen flow rate, as illustrated in Fig. 7. When the oxygen flow rate was raised from 30 to $150 \mathrm{ml} / \mathrm{min}$, the yield of DHB increased from $1.4 \%$ to $2.0 \%$, indicating an increased oxygen flow rate could promote hydroxylation. However, a higher oxygen flow rate required higher operating pressure. As a result, $150 \mathrm{ml} / \mathrm{min}$ was selected as a suitable oxygen flow rate for the reaction.

\subsubsection{Effect of catalyst concentration}

Figure 8 shows the effect of catalyst concentration on phenol hydroxylation. As the catalyst concentration was increased up to $48.8 \mathrm{~g} / \mathrm{L}$, the yield of DHB increased from $1.1 \%$ to $2.1 \%$. However, as the catalyst concentration was increased further to $53.8 \mathrm{~g} / \mathrm{L}$, the yield of DHB decreased to $1.6 \%$. This is possibly

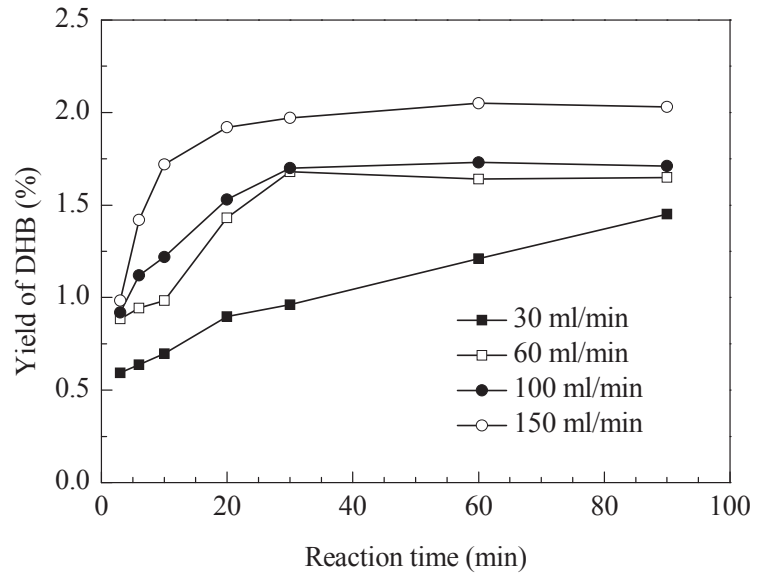

Fig. 7. Effect of oxygen flow on the yield of DHB. Reaction conditions: stirring rate $1460 \mathrm{r} / \mathrm{min}$, catalyst concentration $43.8 \mathrm{~g} / \mathrm{L}$, ascorbic acid concentration $40 \mathrm{~g} / \mathrm{L}$, acetic acid concentration $60 \%$.

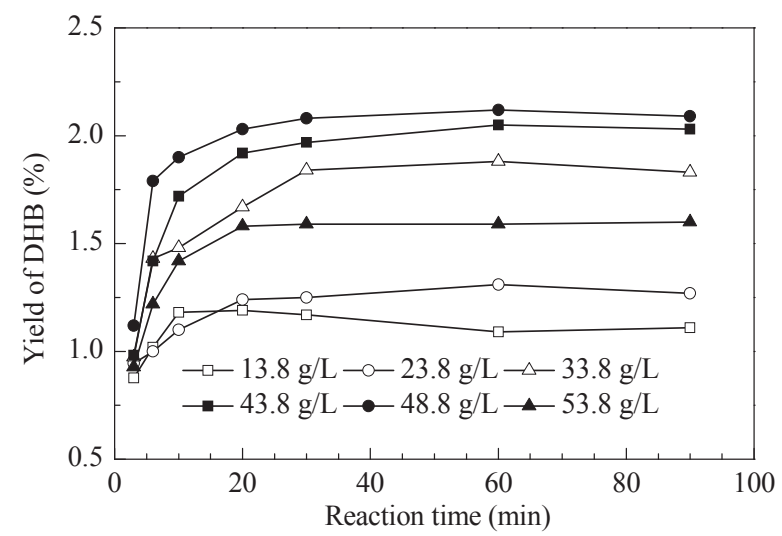

Fig. 8. Effect of catalyst concentration on the yield of DHB. Reaction conditions: stirring rate $1460 \mathrm{r} / \mathrm{min}$, oxygen flow $150 \mathrm{~mL} / \mathrm{min}$, ascorbic acid concentration $40 \mathrm{~g} / \mathrm{L}$, acetic acid concentration $60 \%$.

because the catalyst particles did not mix effectively with the reaction solution at higher catalyst concentration. The optimum catalyst concentration was therefore $48.8 \mathrm{~g} / \mathrm{L}$.

\subsubsection{Effect of ascorbic acid concentration}

In phenol hydroxylation with oxygen, reducing agents such as ascorbic acid, $\mathrm{H}_{2}$ and $\mathrm{CO}$ are needed to activate oxygen in the reaction system. Ascorbic acid is the most effective reducing agent in benzene hydroxylation with oxygen over $\mathrm{Cu}$ catalysts [13]. Therefore, we chose ascorbic acid as the reducing agent in phenol hydroxylation. Figure 9 shows the effect of ascorbic acid concentration on phenol hydroxylation. As the ascorbic acid concentration was increased from 20 to $50 \mathrm{~g} / \mathrm{L}$, the yield of DHB increased from $1.3 \%$ to $2.2 \%$. Further increasing the concentration of ascorbic acid had no obvious effect on the yield of DHB, possibly because the excess ascorbic acid did not directly take part in the reaction because it was oxidized to dehydroascorbic acid [10,14]. It has been reported that excess ascorbic acid might decrease both the reactive oxygen species and yield of DHB $[13,15]$. Thus, the optimum ascorbic acid concentration was $50 \mathrm{~g} / \mathrm{L}$. 


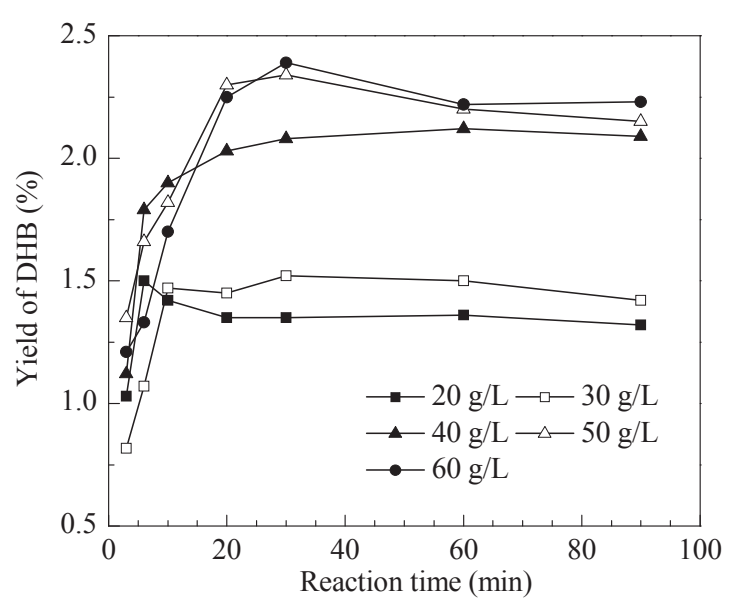

Fig. 9. Effect of ascorbic acid concentration on the yield of DHB. Reaction conditions: stirring rate $1460 \mathrm{r} / \mathrm{min}$, oxygen flow $150 \mathrm{ml} / \mathrm{min}$, catalyst concentration $48.8 \mathrm{~g} / \mathrm{L}$, acetic acid concentration $60 \%$.

\subsubsection{Effect of acetic acid concentration}

In phenol hydroxylation over $\mathrm{Cu}$ catalysts, the concentration of acetic acid determines the amount of $\mathrm{Cu}$ leaching [16]: when the concentration of acetic acid is less than $40 \%$ (by volume), $\mathrm{Cu}$ readily leaches. However, when the concentration of acetic acid is $40 \%-60 \%$, the amount of $\mathrm{Cu}$ leaching obviously decreased, and it was minimal at acetic acid concentrations above $80 \%$. It has been reported that the synthesis of phenol is affected by the reduction of $\mathrm{Cu}^{2+}$ to $\mathrm{Cu}^{+}$, which could be restrained in a strong acid medium, although this was not beneficial for benzene hydroxylation [17].

The influence of acetic acid concentration on the yield of DHB after reaction for $90 \mathrm{~min}$ is presented in Fig. 10. The yield of DHB related to the acetic acid concentration followed the order: $0 \%>80 \%>20 \%>60 \%>40 \%>100 \%$, which might be for the following reasons. When the concentration of acetic acid was below 40\%, many $\mathrm{CuO}$ particles leached into the reaction solution, so more free $\mathrm{Cu}^{2+}$ ions were present. These $\mathrm{Cu}^{2+}$ ions were readily reduced to $\mathrm{Cu}^{+}$, so the yield of DHB was higher at lower acetic acid concentration [17]. As the concentration of acetic acid was increased, the amount of leached $\mathrm{Cu}$ rapidly

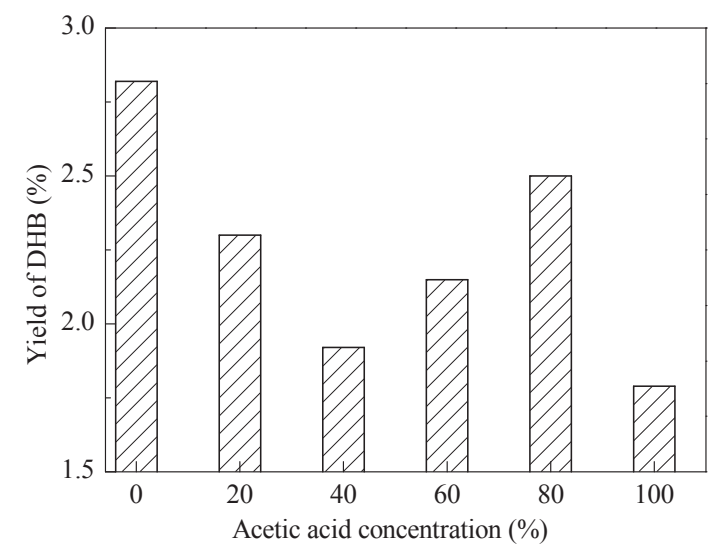

Fig. 10. Effect of acetic acid concentration on the yield of DHB. Reaction conditions: stirring rate $1460 \mathrm{r} / \mathrm{min}$, oxygen flow $150 \mathrm{ml} / \mathrm{min}$, catalyst concentration $48.8 \mathrm{~g} / \mathrm{L}$, ascorbic acid concentration $50 \mathrm{~g} / \mathrm{L}$.

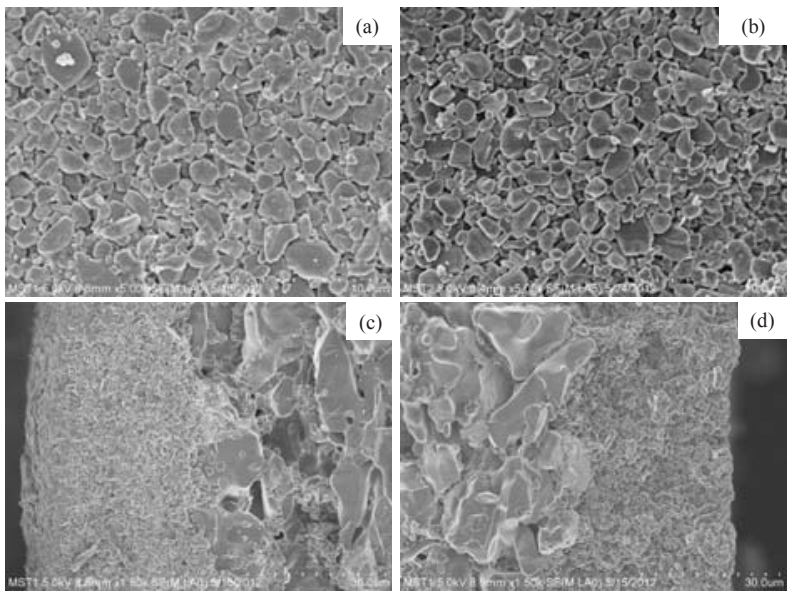

Fig. 11. SEM images of the surface and cross-sections of fresh membrane $(a, c)$ and used membrane $(b, d)$.

decreased and the $\mathrm{CuO}$ species on the support became the active sites for hydroxylation. A higher acetic acid concentration restrained $\mathrm{Cu}$ leaching, resulting in more $\mathrm{CuO}$ species on the support and a higher yield of DHB. When the concentration of acetic acid was increased to $100 \%$, the reduction of $\mathrm{Cu}^{2+}$ to $\mathrm{Cu}^{+}$ was restrained, leading to a lower yield of DHB. The amount of $\mathrm{Cu}$ in the reaction solution after the reaction measured by inductively coupled plasma spectrometry was 0.19 and $0.049 \mathrm{~g}$ for acetic acid concentrations of $0 \%$ and $80 \%$, respectively, indicating that $\mathrm{Cu}$ leaching occurred readily at lower concentrations of acetic acid. Taking into account the recycling of catalyst, the optimum acetic acid concentration was $80 \%$.

According to the above analysis, the optimal operating conditions for phenol hydroxylation with oxygen are as follows: stirring rate of $1460 \mathrm{r} / \mathrm{min}$, oxygen flow of $150 \mathrm{ml} / \mathrm{min}$, catalyst concentration of $48.8 \mathrm{~g} / \mathrm{L}$, ascorbic acid concentration of $50 \mathrm{~g} / \mathrm{L}$ and acetic acid concentration of $80 \%$. Under these operating conditions, the yield of DHB was $2.5 \%$, which was lower than that obtained using a biomimetic catalyst [18]. However, compared with the biomimetic catalyst, the preparation of supported $\mathrm{CuO}$ catalyst was simple and the reaction conditions were mild. To further improve the yield of DHB, the catalyst preparation and use of a ceramic membrane distributor with smaller pore size should be investigated.

\subsection{Membrane material stability}

The stability of the ceramic membranes were investigated by observing the fresh and used membranes by FESEM, as shown in Fig. 11. The ceramic membrane surface did not change obviously and the thickness of the top layer of membrane remained about $30 \mu \mathrm{m}$ after reaction. This indicates the ceramic membrane used in phenol hydroxylation possessed excellent thermal and chemical stability.

\section{Conclusions}

A CuO/ $/ \mathrm{TiO}_{2}$ catalyst was successfully prepared by impregnation for subsequent phenol hydroxylation with oxygen. The 


\title{
Graphical Abstract
}

Chin. J. Catal., 2013, 34: 200-208 doi: 10.1016/S1872-2067(11)60512-3

\section{Enhanced phenol hydroxylation with oxygen using a ceramic membrane distributor}

CHEN Rizhi*, BAO Yaohui, XING Weihong, JIN Wanqin, XU Nanping

Nanjing University of Technology

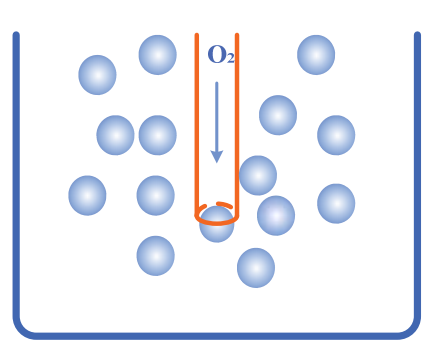

Direct feeding mode

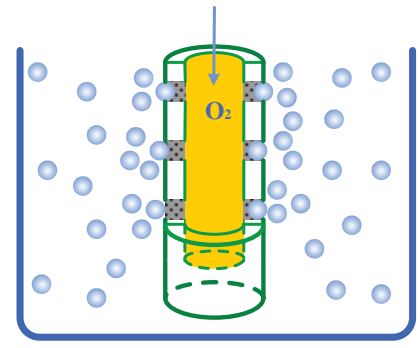

Membrane distributor

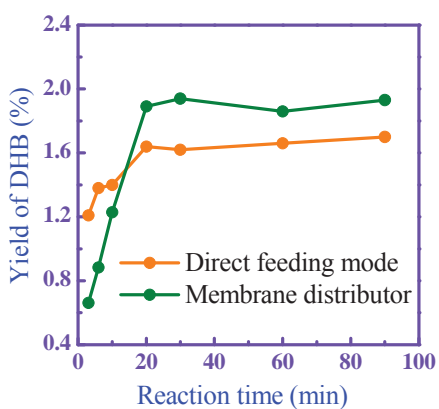

The membrane distributor could provide many small oxygen bubbles, increase the volumetric oxygen transfer coefficient and enhance the gas-liquid mass transfer, resulting in a higher dihydroxybenzene (DHB) yield.

$\mathrm{CuO}$ species interacted strongly with the $\mathrm{TiO}_{2}$ support. A porous ceramic membrane was used as a distributor to control the supply of oxygen during phenol hydroxylation. Compared to the direct feeding mode, the membrane distributor increased both the volumetric oxygen transfer coefficient and the yield of DHB. The ceramic membrane also exhibited excellent thermal and chemical stability. These results suggest that a membrane distributor is an effective way to increase gas-liquid mass transfer that may be used in many reactions in addition to phenol hydroxylation with oxygen.

\section{References}

[1] Elvers B, Hawkins S, Schultz G. Ullmans encyclopedia of chemical technology. 5th Ed. New York: VCH Publishing, 1992. 342

[2] Rao P R H P, Ramaswamy A V. Appl Catal A, 1993, 93: 123

[3] Lu C J, Chen R Z, Xing W H, Jin W Q, Xu N P. AIChE J, 2008, 54: 1842

[4] Courteix A, Bergel A. Enzyme Microb Technol, 1995, 17: 1087

[5] Coronas J, Menendez M, Santamaria J. Chem Eng Sci, 1994, 49: 2015

[6] Jiang H, Meng L, Chen R Z, Jin W Q, Xing W H, Xu N P. Ind Eng Chem
Res, 2011, 50: 10458

[7] Hamdy M S, Mul G, Wei W, Anand R, Hanefeld U, Jansen J C, Moulijn J A. Catal Today, 2005, 110: 264

[8] Wang L P, Kong A G, Chen B, Ding H M, Shan Y K, He M Y.J Mol Catal A, 2005, 230: 143

[9] Tang H L, Ren Y, Yue B, Yan S R, He H Y.J Mol Catal A, 2006, 260: 121

[10] Dong Y L, Niu X Y, Zhu Y J, Yuan F L, Fu H G. Catal Lett, 2011, 141: 242

[11] Lasson P 0, Andersson A, Wallenberg L R, Svensson B. J Catal, 1996, 163: 279

[12] Puskeiler R, Weuster-Botz D. J Biotecnol, 2005, 120: 430

[13] Battistel E, Tassinari R, Fornaroli M. J Mol Catal A, 2003, 202: 107

[14] Gao X H, Xu J. Catal Lett, 2006, 111: 203

[15] Masumoto Y, Hamada R, Yokota K, Nishiyama S, Tsuruya S. J Mol Catal A, 2002, 184: 215

[16] Kanzaki H, Kitamura T, Hamada R, Nishiyama S, Tsuruya S. J Mol Catal A, 2004, 208: 203

[17] Miyahara T, Kanzaki H, Hamada R, Kuroiwa S, Nishiyama S, Tsuruya S.J Mol Catal A, 2001, 176: 141

[18] Zhong R G, She Y B, Wang Y H, Jiao R, Lü J T, Zhen Y (钟儒刚, 余 远斌, 王云海, 焦蓉, 吕江涛, 甄岩). CN 1556084. 2004

\section{陶瓷膜分布器强化氧气氧化苯酚羟基化反应}

\author{
陈日志*, 包耀辉, 邢卫红, 金万勤, 徐南平 \\ 南京工业大学材料化学国家重点实验室, 江苏南京210009
}

摘要: 采用浸渍法制备 $\mathrm{CuO} / \mathrm{TiO}_{2}$ 催化剂,利用 $\mathrm{X}$ 射线衍射、透射电镜、程序升温还原等技术对催化剂进行了表征, 结果表明, $\mathrm{CuO}$ 以 分散态和晶体两种形式存在, 且与载体有强的相互作用. 以陶瓷膜为分布器控制氧气的进料, 进行了 $\mathrm{CuO} / \mathrm{TiO}_{2}$ 催化氧气氧化苯酚 差基化反应. 与直接通入氧气方式相比, 采用孔径为 $0.5 \mu \mathrm{m}$ 的陶瓷膜控制进氧, 可使苯二酚收率提高 $13 \%$, 这主要是由于采用陶瓷膜 作为氧气进料分布器可以提供大量具有微小尺寸的氧气气泡, 提高体积溶氧系数, 增强气液传质效果. 在优化的反应条件下, 苯二 酚收率达 $2.5 \%$. 对使用后的陶瓷膜进行扫描电镜表征, 发现陶瓷膜具有良好的稳定性.

关键词: 苯酚; 羟基化; 氧气; 陶瓷膜; 膜分布器 
收稿日期: 2012-11-30. 接受日期: 2012-12-20. 出版日期: 2013-01-20.

*通讯联系人. 电话: (025)83172286; 传真: (025)83172292; 电子信箱: rizhichen@njut.edu.cn

基金来源：国家科技支撑计划(2011BAE07B05)，国家高技术研究发展计划(2012AA03A606)，国家自然科学基金(20990222, 21106061).

本文的英文电子版由Elsevier出版社在ScienceDirect上出版(http://www.sciencedirect.com/science/journal/18722067).

\section{1. 前言}

苯二酚是重要的化工原料 ${ }^{[1]}$. 苯酚羟基化制备苯二 酚是一种绿色合成工艺, 该法以苯酚为原料, 经过氧化物 氧化生成邻、对苯二酚, 克服了传统方法规模小、反应 过程 “三废”多等缺点, 受到广泛关注. 苯酚羟基化法的 氧化剂主要有双氧水 ${ }^{[2,3]}$ 、氧气 ${ }^{[4]}$ 等. 其中氧气价格低廉、 来源广泛, 无环境污染, 是优选的氧化剂用于苯酚羟基化 反应时, 可避免深度氧化, 具有原子经济性.

氧气作为氧化剂进行苯酚羟基化反应的关键在于 对氧气进行活化产生活性氧, 并且提高它在反应体系中 的分散度、加强传质. 多孔陶瓷膜具有大量规整的微米 或纳米级孔道, 利用多孔陶瓷膜作为气体进料分布器, 可以提供大量具有微小尺寸的氧气气泡, 提高反应器中 的气液传质效果, 促进反应的进行. Coronas 等 ${ }^{[5]}$ 将陶瓷 膜作为气体分布器, 用于甲烷的氧化偶联反应, 相比固 定床反应器, 反应的选择性得到了很大的提高. 在本课 题组前期工作中 ${ }^{[6]}$, 利用陶瓷膜作为双氧水的进料分布 器进行分子篎催化苯酚羟基化制苯二酚, 可明显提高产 物选择性. 而采用陶瓷膜作为氧气分布器进行苯酚羟基 化反应还未见报道.

本文采用浸渍法制备 $\mathrm{CuO} / \mathrm{TiO}_{2}$ 催化剂, 并使用 $\mathrm{X}$ 射 线衍射(XRD)、透射电镜(TEM)、程序升温还原(TPR) 等技术对其微结构进行表征, 并尝试将多孔陶瓷膜用作 氧气分布器进行 $\mathrm{CuO} / \mathrm{TiO}_{2}$ 催化苯酚羟基化反应, 强化物 料的传质效果, 提高反应收率. 采用亚硫酸盐法研究膜 分布器对反应器中体积溶氧系数的影响, 然后考察苯酚 羟基化体系中膜分布器的加入对反应的影响, 并对反应 条件进行了优化.

\section{2. 实验部分}

\section{1. 催化剂的制备与表征}

铜催化剂被广泛用于有机合成, 特别是液相氧化反 应体系中 ${ }^{[7 ~ 10]}$. 据报道, 高分散的铜是进行苯酚羟基化的 活性中心 ${ }^{[10]}$. 本文采用浸渍法制备 $\mathrm{CuO} / \mathrm{TiO}_{2}$ 催化剂, 并 用于氧气氧化苯酚羟基化反应. 称取一定量的三水硝酸 铜(AR, 上海新宝精细化工)及锐钛矿 $\mathrm{TiO}_{2}$ 载体 (青岛攀 枝花钛业公司)加入 $50 \mathrm{ml}$ 水中, 磁力搅拌 $8 \mathrm{~h}$ 后, 利用旋转
蒸发仪蒸干水分,并在 $373 \mathrm{~K}$ 干燥, 研磨后于 $673 \mathrm{~K}$ 炦烧 $5 \mathrm{~h}$, 制得的催化剂记为 $\mathrm{CuO} / \mathrm{TiO}_{2}$, 其中 $\mathrm{Cu}$ 含量为 $7 \%$.

采用德国Bruker公司D8-Advance型X射线分析仪对 催化剂进行XRD表征, $\mathrm{Cu} K_{\alpha}$ 射线, 扫描速率 $0.2 \%$, 管电 压 $40 \mathrm{kV}$, 管电流 $30 \mathrm{~mA}$. TPR 实验在日本 $\mathrm{BEL}$ 公司的 BELCAT-A型化学吸附仪上进行, 样品先在 $573 \mathrm{~K}$ 用 $\mathrm{Ar}$ 气 吹扫 $2 \mathrm{~h}$, 冷却至 $323 \mathrm{~K}$, 然后在 $10 \% \mathrm{H}_{2} / \mathrm{Ar}$ 气氛中, 以 10 $\mathrm{K} / \mathrm{min}$ 升温至 $1023 \mathrm{~K}$. 采用日本 JEOL 公司的 JEM-2011(HR)型TEM表征催化剂的形貌, 样品置于乙醇 溶液中超声分散, 其悬浮液滴加到覆有铜网的碳膜上晾 干后进行测试.

\section{2. 苯酚羟基化}

氧气氧化苯酚羟基化反应在如图1所示的反应器内 进行. 反应器主要包括恒温水浴槽、反应器、膜组件、 流量计和氧气钢瓶等. 玻璃反应器的体积为 $250 \mathrm{ml}$. 陶瓷 膜(由江苏久吾高科技股份有限公司提供)的内外径分别 为 8 和 $12 \mathrm{~mm}$, 长度为 $6 \mathrm{~cm}$; 膜的一端采用釉封密封, 氧气 由另一端进入膜中, 再经膜孔出与反应液接触并反应, 氧 气流速由转子流量计控制.

称取一定量的抗坏血酸(AR, 国药集团化学试剂有 限公司)、 $\mathrm{CuO} / \mathrm{TiO}_{2}$ 催化剂、 $20 \mathrm{ml}$ 苯酚(AR, 国药集团化 学试剂有限公司) 以及 $200 \mathrm{ml}$ 不同体积浓度醋酸(AR, 上 海申博化工有限公司)水溶液 $(200 \mathrm{ml}$ )加到反应器中, 加 热至 $308 \mathrm{~K}$, 利用陶瓷膜分布进料氧气, 反应 $90 \mathrm{~min}$ 后取 样分析.

反应液稀释后用Aglient 1200型高效液相色谱分析, 并采用外标法测定苯酚、苯二酚浓度. 分析条件为: 色 谱柱, ZORBAX Eclipse XDB-C18, 250×4.6 mm; 柱温 $303 \mathrm{~K}$, 流动相为 $V$ (甲醇): $V$ (水) $=40: 60$; 流速 $1 \mathrm{ml} / \mathrm{min}$, 检 测波长 $277 \mathrm{~nm}$, 进样量 $5 \mu \mathrm{l}$.

陶瓷膜的微结构采用日本JEOL公司 S-4800型场发 射扫描电镜(SEM)表征.

\section{3. 结果与讨论}

\section{1. 催化剂的物性表征}

\subsubsection{XRD结果}

图 2 为 $\mathrm{CuO} / \mathrm{TiO}_{2}$ 和 $\mathrm{TiO}_{2}$ 样品的XRD谱. 可以看出, 与 载体 $\mathrm{TiO}_{2}$ 相比, $\mathrm{CuO} / \mathrm{TiO}_{2}$ 在 $2 \theta=35.5^{\circ}, 39.0^{\circ}$ 处明显多出 
两个衍射峰, 分别对应于单斜相氧化铜的(-111)和(111) 晶面, 但其衍射峰强度较弱, 可能是由于氧化铜粒径小或 结晶度较低所致。

\subsubsection{TEM结果}

图3为 $\mathrm{CuO} / \mathrm{TiO}_{2}$ 催化剂的 TEM及HRTEM照片. 由图 可见, $\mathrm{TiO}_{2}$ 载体表面上比较松散地排布有颗粒状物质, 从 内插图可以看到这种颗粒状物质为晶体, 颗粒尺寸在 3.0 $\mathrm{nm}$ 左右, 且晶格间距为 $0.186 \mathrm{~nm}$ 的晶格条纹呈周期性出 现, 对应于氧化铜(-202)晶格面的晶格间距, 说明在 $\mathrm{TiO}_{2}$ 载体表面负载了氧化铜晶体, 且分散得较好.

\subsubsection{TPR结果}

图4显示了为 $\mathrm{CuO} / \mathrm{TiO}_{2}$ 催化剂的 TPR谱. 由图可见, 样品在 443,541 和 $610 \mathrm{~K}$ 处出现明显的特征峰, 且后二者 峰面积明显高于前者. Lasson等 ${ }^{[1]}$ 研究了 $\mathrm{CuO} / \mathrm{TiO}_{2}$ 催化 剂TPR谱, 发现 $453 \mathrm{~K}$ 处还原峰对应于单层分散态氧化铜 的还原; 503 553 K 处还原峰对应于晶体氧化铜的还原. 因此, 可将样品位于 $443 \mathrm{~K}$ 处还原峰对应于单层分散态 氧化铜的还原; $541 \mathrm{~K}$ 处为晶体氧化铜的还原; $610 \mathrm{~K}$ 处 可能为与载体具有更强相互作用的晶体氧化铜的还原. 由此可知, $\mathrm{TiO}_{2}$ 载体上负载的氧化铜以晶体与单层分散 态两种形式存在,且以前者形式为主.

\section{2. 膜分布器对苯酚羟基化反应的影响}

采用亚硫酸盐法 ${ }^{[12]}$ 测定了使用膜分布器后反应体 系中体积溶氧系数, 并与直接通入氧气(采用聚氨酯(PU) 管进料)进行对比, 结果如表1所示, 使用氧化铝陶瓷膜 (孔径为 $0.5 \mu \mathrm{m}$ ) 或莫来石陶瓷膜 (孔径 $1 \mu \mathrm{m}$ ) 作为膜分布 器进氧时, 反应器内体积溶氧系数约是直接通入氧气方 式的 8 倍. 这主要是由于利用多孔陶瓷膜作为分布器进 氧, 减小了氧气气泡直径, 增加了气液传质面积, 从而提 高氧气在反应液中的传质能力.

图 5 为采用氧化铝陶瓷膜和莫来石陶瓷膜作为氧气 分布器进行苯酚羟基化反应结果, 并与直接通入氧气进 行比较. 由图可见, 使用两种陶瓷膜分布器均可提高苯 二酚收率, 特别是利用孔径为 $0.5 \mu \mathrm{m}$ 的氧化铝陶瓷膜时, 苯二酚收率提高了 $13 \%$. 图6为对搅拌速度的影响. 可以 发现在实验范围内, 增加摚拌速度可明显提高苯二酚收 率,因此, 扩散控制是该反应过程的控制步骤. 结合表 1 可 以看出, 在反应器中引入膜分布器, 可以明显提高体积溶 氧系数, 强化氧气在反应液中的传质能力. 这是苯二酚 收率增加的主要原因. 还可以看出, 随反应时间的延长, 苯酚转化率基本呈现上升趋势, 而苯二酚选择性逐渐下 降(结果未显示), 总体上苯二酚收率先上升后趋于稳定.
苯二酚选择性下降主要是由于其深度氧化成苯醌或其 它副产物所致 ${ }^{[6]}$. 引入膜分布器后, 苯二酚收率的增加程 度小于体积溶氧系数的增加程度, 说明还有其他因素, 如 搅拌速度、氧气流量等影响苯酚羟基化反应过程. 小孔 径的膜作为分布器时更有利于苯二酚的生成, 但进一步 减小膜孔径, 导致膜分布器的操作压力显著增加, 故选择 孔径为 $0.5 \mu \mathrm{m}$ 比较适宜.

\section{3. 反应参数对氧气氧化苯酚羟基化反应的影响}

\subsection{1. 搅拌速度的影响}

图6为搅拌速度对苯酚羟基化反应的影响. 由图可 见, 随着摚拌速度的提高, 苯二酚收率随之倍加, 说明提 高摚拌速度减少了气液固之间的扩散阻力, 促进了反应 的进行. 当搅拌速度为 $1460 \mathrm{r} / \mathrm{min}$ 时, 苯二酚收率为 $1.7 \%$, 比无摚拌时的提高了近 2 倍. 进一步提高转速, 在反应器 中心出现漩浴, 导致膜与反应液不能充分接触. 因此, 选 择搅拌速度为 $1460 \mathrm{r} / \mathrm{min}$.

\subsection{2. 氧气流量的影响}

图6为氧气流量对苯二酚收率的影响. 由图可见, 当 氧气流量从 30 提高到 $150 \mathrm{ml} / \mathrm{min}$ 时, 苯二酚收率从 $1.4 \%$ 提高到 $2.0 \%$, 说明增加氧气流量有利于反应的进行. 但 继续提高氧气流速, 氧气透过膜需要更高的压力, 考虑 到实际操作条件, 故氧气流量宜为 $150 \mathrm{ml} / \mathrm{min}$.

\subsection{3. 催化剂浓度的影响}

图8为催化剂浓度对苯酚羟基化反应的影响. 由图 可见, 当催化剂浓度低于 $48.8 \mathrm{~g} / \mathrm{L}$ 时, 苯二酚收率随着催 化剂浓度的增加由 $1.1 \%$ 逐渐增至 $2.1 \%$; 至 $53.8 \mathrm{~g} / \mathrm{L}$ 时, 反 而降至 $1.6 \%$. 这可能是由于当催化剂过量时, 它与反应物 无法充分混合, 故选择催化剂浓度为 $48.8 \mathrm{~g} / \mathrm{L}$.

\subsection{4. 抗坏血酸浓度的影响}

氧气氧化苯酚羟基化反应体系需加入还原剂来活 化氧, 如抗坏血酸、氢气、一氧化碳等. 以铜为催化剂进 行氧气氧化苯羟基化反应时, 抗坏血酸被认为是最有效 的还原剂 ${ }^{[13]}$. 本文也考察了抗坏血酸浓度对苯二酚收率 的影响, 结果见图9. 可以看出, 随着抗坏血酸浓度从 20.0 增加到 $50.0 \mathrm{~g} / \mathrm{L}$, 苯二酚收率从 $1.3 \%$ 提高到 $2.2 \%$; 至 $60.0 \mathrm{~g} / \mathrm{L}$, 苯二酚收率变化不大, 这是由于多余的抗坏血 酸并未直接参与反应, 而被氧化为脱氢抗坏血酸 ${ }^{10,14]}$. 也 有人认为, 多余的抗坏血酸会降低活性氧种类, 不利于苯 二酚生成 ${ }^{[13,15]}$, 故选择抗坏血酸浓度为 $50.0 \mathrm{~g} / \mathrm{L}$.

\subsection{5. 醋酸浓度的影响}

采用铜系催化剂进行苯羟基化反应时,催化剂活性 组分的流失量与醋酸浓度有关 ${ }^{[16]}$. 通常醋酸体积浓度 
低于 $40 \%$, 活性组分的流失量维持在一个较高的水平; 当醋酸浓度为 $40 \%$ 6 $0 \%$ 时, 活性组分流失量迅速下降; 至 $80 \%$ $100 \%$ 时活性组分流失量最小. 苯酚的生成与 $\mathrm{Cu}^{2+}$ 还原为 $\mathrm{Cu}^{+}$的过程有关 ${ }^{[17]}$, 在强酸的环境下会抑制 该还原过程的发生, 不利于苯羟基化反应进行.

图 10 为反应 $90 \mathrm{~min}$ 时苯二酚收率随醋酸浓度的变 化. 由图可见, 不同醋酸浓度时苯二酚收率大小顺序为: $0 \%>80 \%>20 \%>60 \%>40 \%>100 \%$. 这可能是由于膜分布 器的加入使得反应器内的传质能力提高, 从而促进反应 进行; 同时由于醋酸浓度低于 $40 \%$ 时, 大量氧化铜从载 体上流失到反应液中, 从而形成游离态的 $\mathrm{Cu}^{2+}$, 后者更容 易被还原, 因此低浓度的醋酸有利于苯二酚的生成 ${ }^{[17]}$; 当醌酸浓度增加, 活性组分流失量迅速下降, 此时载体上 活性组分成为催化反应进行的活性中心, 由于高浓度的 醋酸阻止活性组分流失, 因此苯二酚收率随醋酸浓度增 加而增加. 当醋酸浓度达到 $100 \%$ 时, 由于强酸对 $\mathrm{Cu}^{2+}$ 还 原的抑制作用, 导致苯二酚收率降低. 当醋酸浓度为 $0 \%$ 和 $80 \%$ 时, 反应后的反应液中铜含量分别为 0.19 和 0.049 $\mathrm{g}$ (ICP测定), 说明醋酸浓度低时, 氧化铜流失量较为严 重. 为了实现催化剂重复利用, 故选择醋酸浓度为 $80 \%$ 的 水溶液作为溶剂进行反应.
综上可见, 优化的陶瓷膜分布器强化氧气氧化苯酚 羟基化反应条件为: 摚拌速度 $1460 \mathrm{r} / \mathrm{min}$, 氧气流量 150 $\mathrm{ml} / \mathrm{min}$, 催化剂浓度 $48.8 \mathrm{~g} / \mathrm{L}$, 抗坏血酸浓度 $50.0 \mathrm{~g} / \mathrm{L}$, 醋酸 浓度 $80 \%$. 此时苯二酚收率达 $2.5 \%$, 低于仿生催化剂 ${ }^{[18]}$ 等的. 但本文催化剂制备过程简单, 反应操作条件温和. 为进一步提高苯二酚收率, 下一步工作将围绕催化剂研 制及更小孔径陶瓷膜分步器的使用等方面展开研究.

\section{4. 膜材料的稳定性}

为了考察陶瓷膜稳定性, 对新鲜的及使用后的膜进 行SEM表征, 结果见图 11. 可以看出,使用后膜面没有明 显的变化, 膜厚度基本维持在 $30 \mu \mathrm{m}$ 左右, 说明在反应体 系中, 陶瓷膜材料作为氧气分布器时具有良好的稳定性.

\section{4. 结论}

利用浸渍法制备了氧气氧化苯酚羟基化反应用催 化剂 $\mathrm{CuO} / \mathrm{TiO}_{2}, \mathrm{CuO}$ 与 $\mathrm{TiO}_{2}$ 之间的相互作用强. 与传统通 入氧气方式相比, 采用多孔陶瓷膜作为苯酚羟基化的氧 气进料分布器, 可明显提高体积溶氧系数, 从而增加苯 二酚收率. 反应过程中陶瓷膜具有良好的稳定性. 膜分 布器是一种有效的增强气液传质的操作方式, 在氧气氧 化苯酚羟基化反应等体系中具有潜在的应用前景. 